\title{
Requirements demanded of accounting practitioners by the market in the second half of the $19^{\text {th }}$ century ${ }^{\star}$
}

\author{
Angélica Vasconcelos ${ }^{1}$ \\ (D) https://orcid.org/0000-0003-3910-9655 \\ Email: avasconcelos@ucly.fr \\ Adriana Silva ${ }^{2}$ \\ (D) https://orcid.org/0000-0003-1538-6877 \\ Email: adrianarsilva.ars@gmail.com \\ Patrik Gomes ${ }^{2}$ \\ (D) https://orcid.org/0000-0003-0426-8891 \\ Email: franciscopatryk@hotmail.com
}

Cilene Vieira ${ }^{2}$

(D) https://orcid.org/0000-0002-4392-3740

Email: vieiracilene@hotmail.com

1 ESDES Lyon Business School, Université Catholique de Lyon, Lyon, France

${ }^{2}$ Universidade Federal do Pará, Instituto de Ciências Sociais Aplicadas, Departamento de Ciências Contábeis, Belém, PA, Brazil

Received on 02.25.2019 - Desk acceptance on 04.01.2019 - $3^{\text {rd }}$ version approved on 10.31.2019 - Ahead of print on 05.11.2020

Editor-in-Chief: Fábio Frezatti

Associate Editor: Eliseu Martins

\section{ABSTRACT}

This study aims to identify the requirements demanded of accounting practitioners by the market in the second half of the $19^{\text {th }}$ century in the state of Pará. Standing out from the existing literature, this study broadens the understanding of the history of the accounting profession as an occupation, through the use of concepts derived from the sociological theory of professions. The relevance of the topic chosen lies in understanding the impact of the requirements demanded of accounting practitioners on the professionalization process and on the modeling of the limits of the occupational structure. The evidence provides the possibility of strengthening the research in the area of accounting history by demonstrating the difficulty of defining what an "accounting practitioner" was, since the expression covered an infinity of employment situations, the performance of various tasks, and included specialized sub-occupations. The study involves archival research, based on job advertisements published in newspapers that circulated in Pará in the period from 1859 to 1888, available from the National Library of Brazil. The requirements analyzed were demographic characteristics (sex, age, nationality, and marital status) and competences. The findings were compared with those of similar studies, as well as with studies that analyze a contemporary period. The results of this research indicate that the market required accounting practitioners to be male, between 12 and 16 years old, with good conduct confirmed by a reference provider, and practical knowledge that was not always restricted to the accounting universe. The findings demonstrate that there was no objective definition of the limits of the identity of the occupation and, in essence, the requirements demanded of accounting practitioners in the second half of the $19^{\text {th }}$ century persist over time. The contribution of this research consists of broadening and deepening the historical understanding of the nature of the accounting occupation in Pará, an area of less commercial prominence during the second half of the $19^{\text {th }}$ century.

Keywords: accounting history, accounting practitioner, demographic characteristics - Pará, theory of professions, Brazilian job market.

\section{Correspondence address}

Angélica Vasconcelos

ESDES Lyon Business School, Université Catholique de Lyon

10 Place des Archives, 69288

Lyon Cedex 02 - France

*This study was presented at the XV USP Congress on Scientific Initiation in Accounting, São Paulo, SP, Brazil, July of 2018. 


\section{INTRODUCTION}

Accounting practice is based on its own set of abstract concepts used to give reality to certain aspects of daily life by recording them in books of accounts (Hines, 1988). These concepts are important for differentiating accounting practice from other practices in the division of work within the social context (Macdonald, 1999). Recognition of the differentiation of accounting practice and of its practitioners in Brazil has occurred through the State since the end of the $19^{\text {th }}$ century. The Commercial Code of 1850 , for example, made it obligatory for merchants to use bookkeeping, as well as presenting the guarda-livros and caixeiro as auxiliary agents of commerce. In that period, both formed part of the wide and heterogeneous group of workers in commerce, whose occupations and attributions were still not very well defined (Popinigis, 2007).

It is considered that every occupation has a history that can be partly described by the changes in the activities carried out, in the values that are given to them, and in the environment in which the occupation occurs (Hughes, 2009). Thus, in order to understand a profession in the present, it is appropriate to understand it as an occupation, that is, to understand its history. This study, therefore, focuses on the period in which the people who practiced accounting were not considered a "particular group," nor was accounting itself a defined area in the social division of work, in order to answer the following problem-question: what were the requirements demanded of accounting practitioners by the market in the $19^{\text {th }}$ century? Here, the term "accounting practitioner" is used instead of "accounting professional," as the aim is to establish the relationship with the concept of occupation and avoid transposing the modern sociological concept (Loraux, 1992) of the term "profession" (Macdonald, 1999) to another time. Considering "requirements" as "a thing that is necessary and essential" or even "an essential condition or exigency," this study is particularly interested in the demographic characteristics and competences of accounting practitioners. The search for the requirements will use as its primary source job advertisements published in the period from 1859 to 1888 in newspapers printed in the province of Pará, currently available from the National Digital Library of Brazil (BNDigital).

In Brazil, the literature related to the accounting practitioners who worked prior to the recognition of the profession, in 1946, has been mainly developed by historians (e.g., Câmara, 2007; Martinho, 1976, 1993; Oliveira, 2013; Popinigis, 2007; Santos, 2009). Such studies concentrate their analyses on the provinces of Rio de Janeiro, Bahia, and Pernambuco, probably because in the imperial era they were already considered to be the ones that had a prominent commercial sector, worthy of extra tax treatment in relation to the rest (Law n. 60, of October $20^{\text {th }}$ of 1838). Areas of less commercial prominence, such as the province of Pará, were not yet the object of similar research, which warrants the efforts of this study. Thus, this research hopes to contribute to that literature, standing out not only for the geographical area of analysis, but also for being grounded in the sociology of professions and for the critical focus given by comparing the results with contemporary aspects, that is, verifying the persistence of the findings over the long run.

This text was divided into five sections. The first is dedicated to presenting the context of the period analyzed, focusing on questions of a political, economic, and social nature in Pará. The following section presents the theoretical framework that supports the analyses, highlighting discussions available in the literature on accounting practitioners and occupations. Next, the methodological route adopted to carry out the research is revealed. This is followed by a discussion in section 4 comparing the theoretical assumptions with the empirical evidence. Section 5 presents the concluding remarks and recommendations for future research.

\section{POLITICAL, ECONOMIC, AND SOCIAL SCENARIO}

The area that currently constitutes the state of Pará was formally denominated, in the period from 1821 to 1889, the Province of Grão-Pará (Gregório, 2011). Since its political emancipation in 1822, the mood in the Province of Grão-Pará was turbulent and prone to the outbreak of movements that represented the struggles of a majority formed of Indians, mestizos, and slaves. This population was used as a workforce by the white minority, in quasislavery conditions in the activities exploiting drugs from the sertão region (e.g., clove, pepper, medicinal plants), in wood extraction, and fishing. This white minority was formed primarily of Portuguese merchants concentrated in the city of Belém (Lopes, 2002; Nogueira, 2009). A significant portion of the population was illiterate, with 
rates of up to $90 \%$ in some parishes, according to the 1872 census (Census of Brazil in 1872, 1874).

The province experienced moments of instability in the period from 1822 to 1835 . A series of popular uprisings occurred, both in the interior and in the capital. These uprisings were supported by troop soldiers, who were disgruntled with their low wages and with the central and local authorities (Nogueira, 2009). One of these revolts was the Cabanagem (1835-1840), which occurred in the Regency Period. The cabanos - a marginalized population that lived crammed in huts on the edge of rivers and streams - aware of the terrible conditions in which they lived, deposed a series of rulers, as well as demanding better material conditions and the expulsion of the Portuguese. The latter was seen as being responsible for the misery in which the cabanos lived (Salles, 1992).

In Belém and neighboring regions, there was a concentration of mills, constituting one of the first agricultural regions of Grão-Pará, where the most important economic center was developed, led by the exportation of cocoa, rice, sugarcane, and tobacco (Salles, 2004). The Cabanagem heavily affected the economy of Pará with the destruction of all the mills, a target of cabano attacks. These attacks upset sugarcane cultivation and the slavery system, marked by the intense participation of slaves and Indians (Salles, 1992).

After the war years, the economy of Pará recovered through the collection of wild products sent for export to countries in Europe and North America. The main products were, for example, cocoa, rubber, leather, chestnuts, and guarana. From 1840 onward, rubber began to stand out in the list of products exported from Grão-Pará (Lopes, 2002). Rubber became the main product exported from the region in the period from 1847 to 1863 , reaching its peak in the period from 1890 to 1910 (Nogueira, 2009). The beginning of rubber exploitation strengthened the regional finances and economy (Lopes, 2002).

The progress of rubber in the second half of the $19^{\text {th }}$ century contributed to the commercial diversification of the region, the growth of the port and of the banking sector, the dynamization of public transport, and the modernization of the capital. This process enabled the installation of commercial firms, with the commercial elite going on to demand a monopoly over their activities. These commercial privileges came about through resolutions and legislation, resulting from the complicity between the regional elite and the provincial government, which prohibited huckstering, trade carried out by mobile traders not registered with the tax authorities (Lopes, 2002). Commercial activity, in general, was the gateway for many people to join the job market (Câmara, 2007), among whom accounting practitioners warrant mentioning. These were fundamental pieces in the functioning of stores and businesses due to them having knowledge that enables more rational business operations (Martinho, 1976, 1993).

\section{EMPIRICAL AND THEORETICAL BACKGROUND}

This section includes two subsections. The first is dedicated to examining the literature on accounting practitioners, to outline who these individuals would be as a social group. The second subsection presents the concept of occupations.

\subsection{Accounting Practitioners}

During the colonial period in the history of Brazil, and even during the $19^{\text {th }}$ century, accounting practitioners formed part of a group of workers generically called "caixeiros" ("clerks") or, simply, "empregados no comércio" ("commercial employees"). This group is described in the literature as being primarily formed of male individuals (Câmara, 2007; Martinho, 1976, 1993; Popinigis, 2007; Santos, 2009), whether due to the silence of the sources used concerning the presence of females, or the convenience of their customary absence (Perrot, 2005). However, Lima and Popinigis (2017) - using legal cases judged in the civil court of Rio de Janeiro in the middle of the $19^{\text {th }}$ century as a source - recently reported the case of one women described as a "caixeira" in her testimony, who performed the position in the period from 1823 to 1842 .

Under the generic term of "caixeiros" are a variety of occupations labeled with various other denominations, such as bookkeeper, sales assistant, clerical assistant, sales boy, and store attendant (Martinho, 1976, 1993; Popinigis, 2007; Sales, 1761-1773; Santos, 2009). These designations were closely related to roles carried out by the workers and served to position them hierarchically within the group (Popinigis, 2007; Sales, 1761-1773). It is essential to highlight, however, that the division of roles between various workers was only visible inside large commercial houses. If the individual acted in small businesses (e.g., taverns, bars, and small "wets and dries" stores), they would undoubtedly be responsible for a large number of roles ranging from cleaning and tidying the commercial house to keeping records in the books 
of accounts (Câmara, 2007; Martinho, 1993; Popinigis, 2007; Sales, 1761-1773). In general, the tasks carried out by the "caixeiros" altered between manual and intellectual work (Popinigis, 2007).

When joining a commercial house, those aspiring to be accounting practitioners or apprentices, initially occupied the most basic level in the hierarchy. Depending on their interest, apprentices could progressively reach the positions of caixeiro de balcão (over-the-counter clerk), caixeiro de fora (off-site clerk), caixeiro (office clerk), and, finally, at the top of the pyramid, the position of guarda-livros (bookeepper or first clerk) (Figure 1). As it is possible to observe, the term caixeiro label all positions in the middle of the hierarchy. The difference among them is expressed by adding other terms (i.e., "de fora" or "de balcão") that have a direct connection with tasks developed at the business. This fact may explain why all accounting practitioners were socially known as caixeiros.

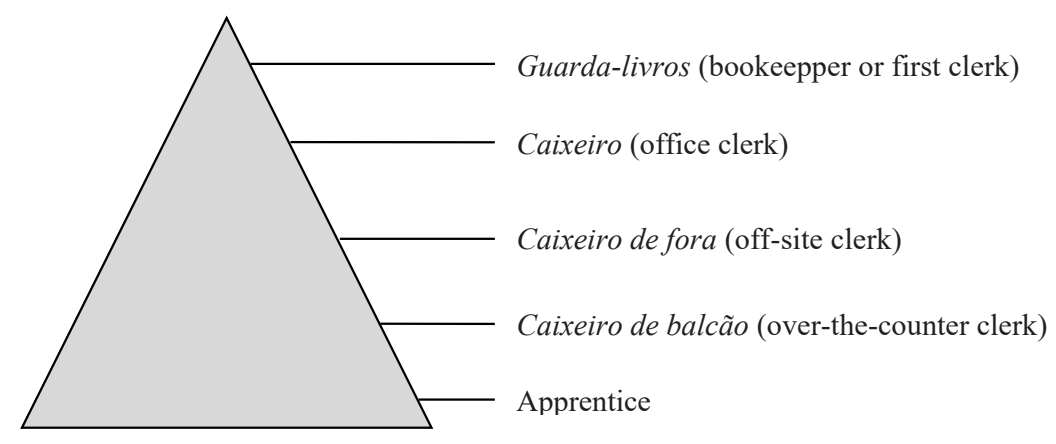

Figure 1 Hierarchy of the accounting practitioners

Source: Elaborated by the authors and based on Sales (1761-1773), Martinho (1976, 1993), Câmara (2007), Popinigis (2007), and Santos (2009).

The apprentice carried out tasks such as cleaning the premises and sorting the merchandise on the shelves, and even acted as an errand boy. With time, the apprentice could serve the public and gradually occupy the position of a caixeiro de balcão (Câmara, 2007; Popinigis, 2007), where being able to deal with customers and the ability to attract passers-by into the stores were highly appreciated skills (Câmara, 2007).

The caixeiro de fora was responsible for tasks such as taking their master's bills and credit notes to collect from customers, going to the customs house to deal with bureaucracy involving the clearance and receipt of merchandise, selling goods in the street, and delivering some highly relevant order (Câmara, 2007; Martinho, 1976, 1993).

The Caixeiro were responsible for the internal operations of the house, being tasked with correspondence and bookkeeping in the subsidiary accounting books (Sales, 1761-1773). On this point, the practitioner was supposed to already have in-depth knowledge of the business in order to answer correspondents with style, maturity, and elegance, so that disputes and litigation were avoided (Sales, 1761-1773).
Guarda-livros occupied the highest level of the hierarchy of accounting practitioners (Martinho, 1993; Popinigis, 2007; Sales, 1761-1773; Santos, 2009). They were responsible for keeping records in the main books of accounts (i.e., day accounts and ledger), elaborating reports (e.g., the general balance sheet of the business and summary of entries), watching over the safe, and supervising the other accounting practitioners of lower hierarchical positions (Sales, 1761-1773). Rising through the hierarchical positions depended on showing honesty and, especially, loyalty to the master over time (Popinigis, 2007). Thus, the guarda-livros was commonly the "caixeiro", who had already risen through all the previous hierarchical positions (Santos, 2009).

Likewise, the historiography reports information on the competences attributed to caixeiros, that is, the set of skills and knowledge acquired through carrying out an activity (Oliveira, 2013). According to the 17th-century lexicologist Silva (1789, p. 427), a competence belongs to "whoever does something the most or best." This study assumes that such competences are socially constructed in various spaces of sociability (e.g., in family, at church, or school) and have three main components: (i) formal knowledge and expertise, which can be translated into 
facts and rules; (ii) know-how, which belongs to the sphere of empirical procedures, such as tacit knowledge of the job that will be developed in the day-to-day practicing of an occupation; and (iii) knowing how to be, social know-how or common sense, which mobilizes strategies and complex reasoning, interpretations, and views of the world (Stroobants, 1997). Since the $16^{\text {th }}$ century, the repertoire of competences included the rules of civility, knowing how to behave well morally in society, which should be learned in the 7 to 12 -year-old age group, whether at school or within the family (Revel, 2009). In hierarchized societies, learning civility was seen as essential for individuals of humble birth, if they intended to pursue any social mobility (Revel, 2009).

Table 1 presents the demographic characteristics and competences listed in the literature. For a better understanding of the findings in the literature, it warrants mentioning that the concept of infancy in the $19^{\text {th }}$ century was different to nowadays, and the employment of minors was considered "normal". The population censuses from
1756 up to 1836 only considered individuals from 0 to 7 years of age as children (Martinho, 1976).

Infancy was not considered as a phase of life in which the child should be separated from the world of adults, having their interests and being initiated in the problems of life through a learning process that required pedagogical techniques and schools separated from family life. The learning, therefore, was of a more empirical, and the child (in this case a small caixeiro) will learn through direct contact with the day-to-day of an adult, where the transmission of culture, from one generation to another, is ensured by the child's affective participation in professional activities. (Martinho, 1976, p. 54)

It warrants mentioning that the accounting practitioners of that period did not have the security of a formal job contract in writing, which left them exposed to the will of their masters. This included long working days (of more than 12 hours), as well as Sundays and holidays and, sometimes, non-payment of wages. For the caixeiros working in small businesses, their job situation was comparable with that of a slave, as they lived in their workplace, and their masters had a direct influence over all aspects of their lives (Popinigis, 2007).

Table 1

Summary of the previous studies on accounting practitioners

\begin{tabular}{|c|c|c|}
\hline Author & Sample & Results \\
\hline Martinho (1976) & $\begin{array}{l}\text { Rio de Janeiro, } \\
\text { from } 1821 \text { to } 1831\end{array}$ & Merchants preferred single Portuguese boys under 14 years of age. \\
\hline Martinho (1993) & $\begin{array}{l}\text { Rio de Janeiro, } \\
\text { the first half of } \\
\text { the 19th-century }\end{array}$ & $\begin{array}{l}\text { Caixeiros had to present an attestation of good conduct and aptitude. Experience in } \\
\text { commercial bookkeeping was expected, as well as a series of moral qualities. }\end{array}$ \\
\hline Popinigis (2007) & $\begin{array}{l}\text { Rio de Janeiro, } \\
\text { from } 1850 \text { to } 1912\end{array}$ & $\begin{array}{l}\text { Caixeiros, almost always Portuguese, should be individuals trusted by the master, } \\
\text { who came when they were still children to work as apprentices. }\end{array}$ \\
\hline Câmara (2007) & $\begin{array}{l}\text { Recife, } \\
\text { the } 1840 \text { s }\end{array}$ & $\begin{array}{l}\text { Portuguese boys started into clerical work when they were around } 12 \text { years old, of } \\
\text { whom much dedication, development, patience, and knowledge of measures and } \\
\text { weights were required. Depending on the role, previous knowledge of commercial } \\
\text { bookkeeping and mastery of a foreign language were demanded. }\end{array}$ \\
\hline Oliveira (2013) & $\begin{array}{l}\text { Recife, } \\
\text { the second half of } \\
\text { the 19th-century }\end{array}$ & $\begin{array}{c}\text { Preferred foreign, mostly young, caixeiros. Cleverness and honesty were considered } \\
\text { more important than the ability to read and write, and previous experience and a } \\
\text { reference provider were required in many cases. }\end{array}$ \\
\hline Santos (2009) & $\begin{array}{l}\text { Bahia, } \\
\text { First Republic (1890-1930) }\end{array}$ & $\begin{array}{c}\text { Predominance of white individuals from the } 12 \text { to } 18 \text {-year-old age group. To } \\
\text { join a commercial house would require being literate and able to carry out four } \\
\text { arithmetical operations. For the most prominent firms, knowledge of commercial } \\
\text { bookkeeping was required, as well as mastery of foreign languages (English, French, } \\
\text { and German). }\end{array}$ \\
\hline
\end{tabular}

Source: Elaborated by the authors.

Working as an accounting practitioner was not perceived by individuals as an activity to be carried out for all their lives, but as something transitory. The dream they pursued was to become traders (Popinigis, 2007). An article published in a newspaper in 1838 about the "occupation of caixeiros" states that this is the "most accessible and most common gateway through which the commercial profession can be entered," that is, into the "highly important class of merchants" (Commercio, 1838 , p. 2). Popinigis (2007, p. 36 ) argues that the desire to realize the dream of being a "future owner ... mitigated the hard and incessant work, both manual and intellectual," 
of clerical work. An important step toward reaching the profession of a businessman was to manage to become an "interested" caixeiro, that is, to obtain participation in the profits of the establishment in which they worked and be "about to become partners" (Popinigis, 2007, p. 45).

\subsection{Occupations}

The sociology of professions in the field of sociology concerned with the implantation, development, training, and institutionalization of professions (Dubar, 2005). The theory of professions, derived from sociology, emphasizes that professions are conceived as occupations that apply a systematic knowledge set with the aim of resolving highly relevant problems for the core values of society (Rueschemeyer, 1964).

The concept of the profession, as well as its meaning, has been widely debated in the sociological literature. Despite the discussions around its concept, some professional attributes are shared among the scholars of professions. These can be defined by the existence of an organizational pattern of specialized work whose main characteristics include: (i) full-time occupation of its members; (ii) standardized training in skills and knowledge; (iii) the existence of institutional devices for self-regulation; and (iv) status and autonomy (Macdonald, 1999). For Carr-Saunders (1993), a "profession” emerges in the social context when a defined number of people start to practice a defined technique based on specialized training and form an association whose aim is to test technical competence through exams.

The Commercial Code of 1850, when addressing the division of work in commerce, labels guarda-livros and caixeiros as auxiliary agents. In other terms, clerical work would be an occupation subordinate to merchants, to which the technical part of the task is delegated, or the "dirty work," which would not be worthy of the merchant (Abbott, 1988; Dingwall, 2008, p. 45). In turn, the merchant would be responsible for making judgments about the business (Commercio, 1838). Thus, the activities called "dirty work" by the literature, in this case, clerical work, would range from sweeping and tidying the commercial establishment to recordkeeping of the business transactions.

The technical competence exams needed for entry into the accounting profession, indicated in the sociological theory as an integral element of the framework of a profession, were initiated late in Brazil, from 2000 onward (Federal Accounting Council [CFC], 2007), despite their existence already featuring in the legislative document (Decree-Law n. 9,295, of May $27^{\text {th }}$ of 1946) that created the CFC, a class entity.
In light of the above, there is evident inadequacy in the transposition of the concept of "profession" to the moment studied in this research. This is because it is possible to observe accounting practice as an occupation that emerges in Brazil in the $19^{\text {th }}$ century following technological changes transferred from Portugal, as well as social changes. For that reason, this study analyzes clerical work as an occupation (Dingwall, 2008; Macdonald, 1999) to outline the singularity of that historical moment concerning the current conceptions proposed by sociology for the term profession, as well as not imputing into it the quality of archaic due to the non-observance of modern criteria.

Dingwall (2008) defines occupation as a unit in the popular taxonomy of work, which emerges from negotiating the limits of one area in the social division of work to establish control of that area, making it familiar, predictable, and manageable. It concerns quite a volatile sociological term whose meaning depends on spatial and temporal questions. However, it can be understood as a social role before that of the profession, in which its practitioners are recognized by society as individuals who carry out a full-time activity that earns them a monetary income to support themselves (Davies, 1980; Dingwall, 2008; Hakim, 1980). It warrants mentioning that not all so-called "economic" activities, which provide incomes for their practitioners, can be considered as an occupation. The notion of personal occupation is based on a series of social developments, which include the separation of home and workplace, mobility within the hierarchy of the group, earnings in money, and continuous remunerated employment (Davies, 1980). Such developments were neither present at the beginning nor at the end of the $19^{\text {th }}$ century (Hakim, 1980). Therefore, considering the temporal limits outlined for this research, the adverts studied here refer, at most, to the occupation of "caixeiros."

This theoretical framework will allow us the historical and sociological dialogue. We will advance with the historical understanding of the characterization of practitioners of the accounting occupation, of the professional agency, and its changes in the current era, inspired by the sociological theory of professions, with the reconception of the study of professionalization.

The reconception movement of sociology focused on the critical spirit of social reality, analyzes, among other facts, the foundations of the profession, including reflections on its deontology, its job market, and the profile of its agents (Martins, 2015). By analyzing the accounting practitioner of the $19^{\text {th }}$ century, we carry out a retrospective reflection and rational and critical analysis of the profile demanded by the job market of the time, 
intending to reformulate, broaden, and transforming the knowledge set that constitutes the previous practical theory regarding accounting professionals. More details about methodological questions appear in the next section.

\section{METHODOLOGY}

The research conducted has the printed newspapers that circulated in Pará as the primary source. Such documents are available on the BNDigital website, which is composed of newspapers, magazines, annuals, bulletins, and serialized publications. It is even possible to find the first newspapers of the empire, and others that marked the history of the press in Brazil. The consultation was carried out by title, year, edition, place of publication, and word(s). To identify the requirements demanded of accounting practitioners in the second half of the $19^{\text {th }}$ century, the sample considers job offer and job search adverts published in the printed newspapers that circulated in Pará. The requirements analyzed were demographic characteristics (sex, age, nationality, and marital status) and competences (formal knowledge, know-how, and knowing how to be). According to Kreniski and Aguiar (2011), by using the written press as a primary research source, it is possible to reconstruct events using the most effective means of communication for propagating information.

According to Neves (2009), the information service provided by newspapers, through classified ads, facilitated the communication between the reading public and/or consumers with an interest in buying, selling, exchanging, renting, lending, donating, conveying personal, religious, and sentimental messages, and advertising and searching for jobs. The terms "procura-se" and "precisa-se" ("sought" and "needed") in the classified ads are present in the Brazilian newspapers of that time, where it was possible to identify the personal characteristics and competences demanded of accounting practitioners. Martinho (1976, 1993) and Câmara (2007) are examples of similar studies that also made use of those adverts published in newspapers to obtain information on clerical work. These studies, together with others (Oliveira, 2013; Popinigis, 2007; Santos, 2009), are used as a reference for comparing the findings regarding practitioners in Pará throughout the analysis to ensure historical integrity.

The temporal delimitation has the concept of occupation expressed by Dingwall (2008) as the based. Therefore, it is a social role before the emergence of the sense of collectivity stated, for example, in the definition of a profession made by Carr-Saunders (1993). The period chosen extends from 1859 to 1888 . The emergence of the newspaper directed toward the job category of accounting practitioners on December $15^{\text {th }}$ of 1889 (O Caixeiro), considered evidence of collective consciousness, justifies the temporal cut-off in 1888. It is necessary to underline the particularity of the period chosen for the place under study (Pará), since associations directed toward the category of practitioners, other evidence of the collective consciousness, already existed in the capital of the Empire (Corte) from 1826 (Popinigis, 2018).

The sample selection centers on newspapers: (i) in daily circulation; (ii) that presented both job offer and job search adverts; and (iii) that had relatively long regularity in the publication of editions. Thus, four newspapers were chosen, responsible for 300 adverts, as can be observed in Table 2.

Table 2

List of newspapers and their job search and job offer adverts by and for accounting practitioners

\begin{tabular}{|c|c|c|c|c|c|}
\hline \multirow[t]{2}{*}{ Newspapers } & \multirow{2}{*}{$\begin{array}{l}\text { Owner/founder/ } \\
\text { editor }\end{array}$} & \multirow[t]{2}{*}{ Period } & \multicolumn{3}{|c|}{$\begin{array}{l}\text { Adverts } \\
\text { (n) }\end{array}$} \\
\hline & & & Search & Offer & Total \\
\hline Gazeta Oficial & $\begin{array}{l}\text { Antônio José Rabelo } \\
\text { Guimarães }\end{array}$ & $1858-1860$ & 8 & 23 & 31 \\
\hline Diário de Belém & $\begin{array}{l}\text { Antônio dos Santos } \\
\text { Campos }\end{array}$ & 1868-1888 & 17 & 94 & 111 \\
\hline O Liberal do Pará & $\begin{array}{l}\text { Manoel Antônio } \\
\text { Monteiro }\end{array}$ & $1869-1888$ & 6 & 39 & 45 \\
\hline Diário de Notícias & Costa \& Campbell & $1881-1888$ & 8 & 105 & 113 \\
\hline Total adverts & & & 39 & 261 & 300 \\
\hline
\end{tabular}

Source: Elaborated by the authors based on data from the sample. 
All the newspapers chosen originate from typographies founded on the initiative of some individuals. Their editorial lines were linked to distinct ideologies (Table 3). Nonetheless, the similarity in the language used to publish the job adverts corroborates with the notion of neutrality of the adverts in relation to news of a political nature (Azevedo, 2009; Rebouças \& Bastos, 2017).

Acquisition of the newspapers could be one-off or via subscription (monthly, quarterly, semestral, or annual) (Table 3). To illustrate, one example of the Diário de
Notícias cost 40 réis in 1881, a value that was considered affordable even for a captured slave (Morel, 2008). For subscribers of the Gazeta Oficial who intended to place an advert, there was no extra cost. For non-subscribers, "whatever was agreed" was charged, it not being possible to identify the real value (Gazeta Official, September of 1858, edition 99, p. 1). The other newspapers omitted that information, which may be explained by the fact that adverts were often published for free in the $19^{\text {th }}$ century (Azevedo, 2009).

Table 3

Value of annual subscription, themes, and ideological links of the newspapers that compose the sample

\begin{tabular}{lcc}
\hline Newspaper & $\begin{array}{c}\text { Annual subscription value } \\
\text { (\$ thousand réis) }\end{array}$ & Subjects published/ideological link \\
\hline Gazeta Oficial & 15 & $\begin{array}{c}\text { Provincial administrative acts and hours of } \\
\text { public offices }\end{array}$ \\
\hline Diário de Belém & 16 & $\begin{array}{c}\text { Policies, news, and business linked to the } \\
\text { conservative party }\end{array}$ \\
\hline O Liberal do Pará & 16 & Linked to the liberal party \\
\hline Diário de Notícias & 12 & Linked to the democratic republican party \\
\hline
\end{tabular}

Source: Elaborated by the authors based on data from the sample.

The identification and selection of adverts for analysis (offer and search) were carried out using the terms "Caixeiro", "Caixeira", "Caxeiro", "Caxeira", and "GuardaLivros" (essentially "Clerk" and "Bookkeeper") in the title of the advert or the body of the text. The terms used were chosen based on the literature (Lima \& Popinigis, 2017; Martinho, 1976, 1993; Popinigis, 2007; Sales, 1761-1773; Santos, 2009). The adverts chosen for analysis were labelled as "search" and "offer." In the former, the "practitioner" or "aspiring practitioner" advertises themself to carry out functions or activities related to clerical work. In the latter, potential "employers" offer positions. In the entire sample, job offer adverts were the majority. The inclusion of job search adverts in the research sample enables doublechecking, through the perception of workers, about the personal characteristics and competences required by the market and that the workers judge to be relevant.

One limitation of this study concerns the quality of the adverts, which only enable an analysis of the lowest levels of the hierarchy of accounting practitioners. Only one job advert was identified that was a "search" for employment as a "guarda-livros." The few or almost inexistence of job "offer" adverts can be explained by the requirement of a relationship of trust between master and employee, normally built up after years of service (Martinho, 1993; Popinigis, 2007; Santos, 2009).

In epistemological terms, this study understands making history as an interpretative process, a product of the historian's activity (Bloch, 1992). Therefore, the narrative used here includes interpretations and explanations of the object under analysis based on the sources consulted. During the analysis, the particular identity of the past is recognized and preserved, ensuring its autonomy in relation to the present. Thus, the data are read through the mental framework of the time. The narrative makes use of vocabulary inherent to the time, making its meaning clear and highlighting similarities or differences in relation to the current concepts, to avoid the reader having an erroneous interpretation. 


\section{RESULTS AND DISCUSSIONS: THE CAIXEIROS OF PARÁ IN THE SECOND HALF OF}

\section{THE $19^{\mathrm{TH}}$ CENTURY}

The presentation of the results will follow the following sequence in this section: (5.1.) the demographic characteristics, (5.2.) the competences demanded, and (5.3.) the relevance of the findings of this research to the present.

\subsection{Demographic Characteristics Required of the Practitioners}

All of the adverts in the sample were meant for males. This fact is derived from an indirect analysis of the adverts, as the sex was not clearly and unequivocally communicated. All the adverts made use of the generic term for the profession, always inflected in the masculine form. Some adverts also simultaneously contained other vocabularies that alluded to the male sex, such as "boy" and "man."

Information about age was present in 160 adverts, as can be observed in Table 4. It was possible to identify three distinct ways of mentioning "age" in the adverts. The most common was the indication of an age group, that is, age does not appear explicitly, but a range of ages. The second most used way was indirect mention through terms that alluded to age. The following are examples of terms used: "menino," "pequeno," "rapazito," and "moço" (all forms of the word "boy" or "young man") (Figure 2). Mention of a specific age was the most uncommon way.

The determination of the number of classes and interval shown in Table 4 did not follow statistical criteria, which would force a "break" in groups defined in the particular documentation from the time. Therefore, age was divided into four intervals. The age group variable is classified as continuous, as the upper limit of one interval is equal to the lower limit of the following one. In the first interval, all the adverts in the explicit age group from 8 to 12 years old (open at the extremities) are included. Thus, for example, the adverts explicitly referring to the 10 to 15-year-old age group (which is between two intervals) were included in the following interval. The association of generic terms in each interval was made by analogy, using as a reference advert that considered both pieces of information, that is, age group and term or specific age and term. Two cases were removed from the analysis as it was impossible to make this association. The terms used in these adverts were specifically "man" and "caixeirinho" ("small clerk").

Table 4

Absolute and relative frequency of the age item in the recruitment adverts for caixeiros in Belém, Pará, in the period from 1859 to 1888

\begin{tabular}{lcccc}
\hline $\begin{array}{l}\text { Intervals } \\
\text { (years) }\end{array}$ & Age group & Terms & Specific age & Total adverts \\
\hline $8-12$ & 9 & 0 & 2 & 11 \\
\hline $12-16$ & 88 & 10 & 6 & 104 \\
\hline $16-20$ & 28 & 15 & 1 & 44 \\
\hline $20-28$ & 1 & 0 & 0 & 1 \\
\hline Total & 126 & 25 & 9 & 160 \\
\hline
\end{tabular}

Source: Elaborated by the authors based on data from the sample.

It can be seen from Table 4 that the entry of accounting practitioners in the second half of the $19^{\text {th }}$ century in Pará normally occurred in the 12 to 16 age group. Therefore, they were individuals who would be practically at the end of elementary education or would have already concluded it (Census of Brazil in 1882, 1874). This characteristic was also perceived in Bahia for the same period (Santos, 2009). According to Câmara (2007), becoming a caixeiro while still very young meant the first stage in the world of work, where clerical work was the most common type of apprenticeship and professional activity for free individuals in that age group. According to Hughes (2009), occupations can vary in their demand and require full and long-lasting commitment from the practitioner of the occupation. 
When the employer was looking for a caixeiro, it was most common to require candidates to be in a particular age group. However, when the practitioner or aspiring practitioner offered themself to carry out clerical work, some term was used to indirectly mention age (Figure 2).
Referencing age in the job offer adverts was not expected, where it was possible to detail the practitioner's behavior as a strategy for increasing their probability of gaining employment, since they were unaware of the specifics of the age desired by potential employers.

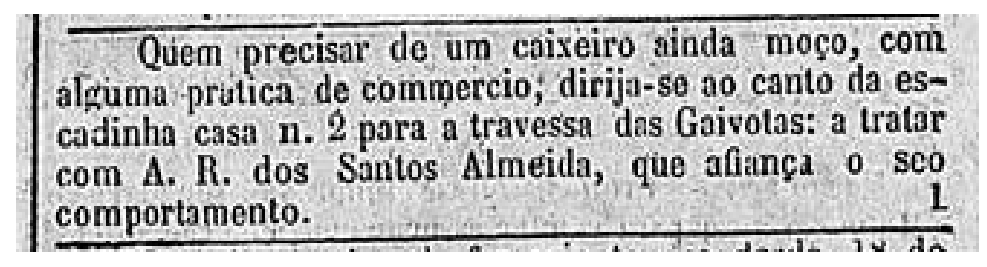

Figure 2 Job search advert referencing age and competence

Note: Translation: "Anyone who needs a boy caixeiro, with some commercial experience, go to the corner of the steps of house n.2 of Travessa das Gaivotas: ask for A.R. dos Santos Almeida, who attests to his behavior."

Source: Gazeta Official, May of 1859, edition 111, p. 3.

Reference to nationality (Figure 3) was present in 31 job adverts in Pará, as a requirement for hiring caixeiros. Despite the small number of adverts, in 30 the nationality mentioned was Portuguese. However, it is not possible to affirm that nationality, in general, and being Portuguese, in particular, was a relevant requirement demanded by the market in the second half of the $19^{\text {th }}$ century in the state of Pará, unlike in the result found by Oliveira (2013) for Recife in the same analysis period.

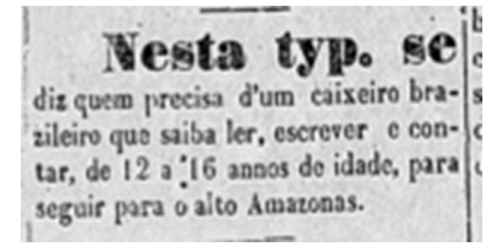

Figure 3 Job offer advert referencing age, nationality, and competences

Note: Translation: "In this typography, it is announced that a Brazilian caixeiro is needed, who can read, write, and count, and is 12 to 16 years old, to go on the high Amazon."

Source: O Liberal do Pará, February of 1870, edition 36, p. 2.

Table 5

Absolute and relative frequency of the experience item in the recruitment adverts for caixeiros in Belém, Pará, in the period from 1859 to 1888

\begin{tabular}{lccc}
\hline Experience in & Sought & Offered & Total adverts \\
\hline Tavern & 1 & 95 & 96 \\
\hline Commerce & 5 & 42 & 47 \\
\hline Interior business & - & 5 & 5 \\
\hline Collection & 1 & 2 & 3 \\
\hline Office & 2 & 1 & 3 \\
\hline Serving at the counter & - & 6 & 6 \\
\hline Other experience & 1 & 6 & 7 \\
\hline Total & 10 & 157 & 167 \\
\hline
\end{tabular}

Source: Elaborated by the authors based on data from the sample.
Of all the adverts, only one explicitly mentioned marital status as a requirement for hiring (job offer advert), were the term "married" was evident. Yet, judging by the age group most commonly reported in the adverts, it is assumed that the employers would be looking for single individuals. Martinho (1993) reports that a large portion of merchants preferred their caixeiros to be single and to live at work, so they were always available to the master any time he needed them.

\subsection{Competences Required of the Practitioners}

Of the three typologies of competences analyzed, the one that was most present was know-how, with 167 adverts that mentioned experience as a requirement for hiring caixeiros. Table 5 presents the experience indicated by the adverts. It is perceived that experience was demanded not only for specific activities of clerical work (Sales, 1761-1773), but also for other activities of a commercial nature. The latter ranged from cleaning the establishment, to delivering door to door, to serving customers at the counter (Popinigis, 2007). 
The term "taberna" ("tavern") (Figure 4) designates, in the period studied, a type of store in which wine is sold or a modest food and drinks store (Popinigis, 2007). Therefore, when this term was mentioned, it is believed that the individual knew how to, for example, serve customers at the counter. This finding is compatible with the results found by Oliveira (2013). For the author, as there was no professional certification to verify experience, it was up to the caixeiro themself to confirm their ability to carry out a task or present a reference from some previous employer as proof.

\section{N'esta typographia se diz quem precisa de un cáixciro pura taberna que tenha 14 annos de idade ou menos e boa conducta.}

Figure 4 Job offer advert for a caixeiro with age and moral quality requirements

Note: Translation: "This typography says who needs a caixeiro for a tavern who is 14 years of age or less and has good conduct."

Source: O Liberal do Pará, October of 1871, edition 237.

In 22 adverts, explicit reference to competence in bookkeeping was found, which can be understand as formal knowledge or know-how. However, it is important to highlight that there were more adverts from people showing they had these competences (13 adverts) than employers making such a request ( 9 adverts). The low demand for caixeiros with that competence may be explained by the fact that there was a hierarchy among the pratitioners in the commercial establishments, in which it was natural to start as an apprentice and, according to their development, rise in position, reaching the level of guarda-livros. That is, the caixeiros with this competence would be hired from among the accounting practitioners of the establishment itself, whose merchant already trusted them, and hardly ever through newspaper adverts.

In only 10 adverts was the requirement to know how to read and write found, all of which were job offers (Figure 3). This result can be evaluated from different perspectives. The first would be that the merchants judged it to be important for the caixeiros to already know how to read and write when they were hired. The second would be that the employers saw, in the social context of the time, certain difficulty in finding people with these competences due to the high local illiteracy rates. Thus, they preferred not to stress it. This result was different from the one found by Oliveira (2013), who verified a greater number of adverts by caixeiros who knew how to read and write offering their services than by employers requesting such knowledge.

Other requirements demanded appear in the newspaper adverts, although less often. Of all the adverts in the sample, seven showed the term "good handwriting," of which four were the accounting practitioner themself affirming having this competence. The ability to carry out arithmetical operations occurred in four adverts, two of which were job offers and two were job searches. Regarding languages (Portuguese, French, and English), only two adverts were found, both of which were job searches. These adverts would probably be by so-called "high commerce" commercial houses, that is, the export and import offices so common in squares of Rio de Janeiro, Bahia, and Pernambuco (Popinigis, 2007). The low frequency corroborates the idea of lower commercial prominence of the province of Pará during the second half of the $19^{\text {th }}$ century.

By relating the result of the age of the caixeiros presented in Table 4 with the results of the experience required in Table 5, it can be verified that, of the 157 adverts that offered places for caixeiros with some experience, in 62 it was possible to perceive that they also demanded a particular age group. With this, it was verified that even though caixeiros were hired prematurely, from the 12 to 16-year-old age group, some experience was already demanded of them. Thus, it is believed that these boys, even though they were young, were already involved in clerical activity even before turning 12 years of age.

The competences of knowing how to be were equally present in the recruitment adverts for caixeiros, primarily addressing questions of a moral or behavioral nature, of civility. Considering that most of the caixeiros lived in the home of their masters, as part of the family, being responsible for collections and payments, it is possible to understand the reason for this requirement. If the merchants had no guarantee of someone's moral qualities, they would not leave their businesses in the hands of that person. This finding similarly confirms, albeit indirectly, the more mundane social group to which accounting practitioners belong. In 44 adverts, "good conduct" requirements were found (Figure 4). According to the $17^{\text {th }}$ century lexicography, the term conduct covers moral procedures, that is, how the individual governs their life (Silva, 1789). In theoretical terms, an employee's conduct is an important aspect that contributes to their individual performance, as individuals with good conduct would be disciplined, obedient, and willing to learn (Revel, 2009). The earlier the individual is exposed to the rules of civility, 
the more effective their learning will be, and its execution is seen as something evident and natural (Revel, 2009).

Possibly, considering that young individuals (of more than 12 years old) can more easily get involved in situations that promote bad conduct, in some cases it was not enough for them to state that they had good conduct, and it was necessary to prove this, by presenting a reference provider. It was up to the practitioner themself to present the reference (Figure 2), that is, the name of some person or, preferably, some prior employer (Oliveira, 2013). Of the 44 adverts, the reference requirement was verified in 17 (13 requested by employers and 4 offered by caixeiros). These requirements were also observed by Martinho (1976, 1993) and Oliveira (2013). Martinho (1976) explains that, in order to be suitable to live with the merchant and their family, caixeiros had to display a series of moral qualities, thus subjecting themselves to the authority of their master. According to Martinho (1993), to receive the title of caixeiro, the "aspirers" would have to present an attestation of previous good conduct and aptitude by their respective master. In Recife, masters considered the accounting practitioners' moral qualities (i.e. cleverness and honesty) to be more important than knowing how to read and write (Oliveira, 2013).

\subsection{Renewal of Accounting}

It is understood that the renewal of accounting implies training a professional plurality. As occurs in social service, it is believed that this plurality is based on different procedures grounded in practical legitimacy (Netto, 2005), given that accounting practitioners have, according to the demand of the market, built a critical view of society and their own activities.

In light of the particular characteristics of the development of society, it is perceived that modernization has adapted accounting to the requirements of the market through (i) a structural-functionalist positioning and (ii) rupture and continuity with the past (Netto, 2005). In the structural-functionalist positioning, there is an observed search for professional guidelines for accounting, which consist of acquiring technical knowledge capable of affecting society. In the case of rupture and continuity with the past, previous studies (Biasibetti \& Feil, 2017; Pires, Ott, \& Damacena, 2009; Rodrigues, Schmidt, \& Santos, 2012), together with this research, reveal that, despite the improvement of old professional accounting practices to meet the new demands of the professional profile, some conservative practices are maintained and, in turn, there are no significant changes in professional practices (Netto, 2005).
This study shows that in the second half of the $19^{\text {th }}$ century, the labor market in Pará demanded both personal characteristics and competences from accounting practitioners. It is no different today. When summarizing their findings in relation to the accounting professional profile required by companies located in Rio Grande do Sul, Biasibetti and Feil (2017) highlight the age factor (i.e., from 26 to 35 years old), experience (i.e., from 4 to 5 years), knowledge of foreign languages (i.e., German), and training in accounting sciences, as well as having "commitment to their work" and "mastery in the areas." It is therefore perceived that the age and experience factors persist to this day, even though they have different profiles, sometimes altered by external impositions.

A rupture, but at the same time continuity with the past, can be observed with relation to the age factor. Age continues to be a requirement for hiring accounting practitioners; however, Decree-Law n. 5,452, of May $1^{\text {st }}$ of 1942 , and its alterations, in effect in the country, prohibit employing children under 14 and lay out rules for individuals in the 14 to 18-year-old age group (articles 402-41).

With relation to the competences of knowing how to be, civility, required in the $19^{\text {th }}$ century (good conduct, good customs, and being diligent), the need for a moral stance stands out above all, given that the caixeiros were included into the world of their masters, forming part of their family and often working directly in the finances of the commercial activity. This moral stance is still required to this day. With the renewal of accounting, the accountant is required, through the professional ethical code, to carry out the profession with zeal, diligence, honesty, and technical capacity, observing the Accounting Principles and the Brazilian Accounting Standards, and safeguarding their clients' interests, without losing their professional dignity or independence (CFC, 2003).

In the $19^{\text {th }}$ century, it was custom to require knowledge related to the area or to the branch of business, which persists today. With modernity, Brazilian accounting has received influences from the Italian school of doctrine, which saw accounting as a science, with its own laws and principles, as well as U.S. accounting pragmatism, which is based on rules (Rodrigues et al., 2012). Both schools have, together with the needs of the government to inspect accounts and generate reliable accounting information (Rodrigues et al., 2012), provided a critical way for the accounting practitioner to act. Nowadays, considering the growing global economic and financial integration of Brazil, the market requires the accounting practitioner to have knowledge of corporate accounting, corporate and tax law, as well as of information technology and 
international convergence (Pires et al., 2009; Rodrigues et al., 2012).

It is therefore understood that the accounting practitioner acts under the ideological influence of an era and is also asked to occupy a certain position in a social organization.

\section{CONCLUDING REMARKS}

We filled a gap in the research by investigating the demographic characteristics and competences required of accounting practitioners in the second half of the $19^{\text {th }}$ century in the state of Pará, specifically in the period from 1859 to 1889 . We revealed that, regarding personal characteristics, the market in Pará in the second half of the $19^{\text {th }}$ century preferred to hire single male accounting practitioners from the 12 to 16 -year-old age group. Concerning competences, we showed that the requirement most demanded by merchants was the previous experience, followed by competence in bookkeeping, knowing how to read and write, having good handwriting, knowing arithmetic, and speaking other languages.

We presented that, in Pará in the $19^{\text {th }}$ century, it was imperative to have knowledge related to the area or to the branch of business in order to obtain a job opportunity in the accounting market. Over the years, influences of the Italian and U.S. schools and the government (Rodrigues et al., 2012) have led to better performance in professional actions by meeting the demands of the government and of society based on theoretical-methodological principles that have sought to improve the traditional accounting practices.

The results found should be analyzed within their context and present limitations. The newspaper adverts only enable an analysis of the lowest levels of the hierarchy of accounting practitioners in the period evaluated. The sample contained only one advert for a guarda-livros, this being a job search. The fact that the role of guardalivros was perceived in the period as a position of trust may explain the almost inexistence of job offer adverts. The "natural" thing would be for this practitioner to have already been in the establishment since they were a child. Thus, the day-to-day work in a long-term basis would provide opportunities to show their loyalty to the master so that, in the future, they could be promoted to guarda-livros.

The contribution of this research consists of broadening and deepening the historical understanding regarding accounting practitioners, the professional agency, and its changes in the current era. By drawing on the explanatory potential of the theory of professions, we contributed to the reconception of the study of professionalization. We contributed to the literature by presenting that the establishment and evolution of the accounting profession should also be considered based on the needs created by the market. Focusing on this type of reflection resulted in the conscious (re)construction of the understanding of the market requirements for exercising accounting activity in practice. Employing critical and rational analysis, we also contributed to the reformulation, extension, and transformation of the knowledge set that constitutes the previous practical theory regarding accounting practitioners. Finally, the investigation of the reality of the accountant's activities in time may allow the creation of conditions for the (potential) reconstruction and reconception of future professional practice.

The research on Brazilian accounting history is still in its infancy. Therefore, continuity of this research would be interesting, with more in-depth studies related to guarda-livros, based on other research sources such as library collections, as well as the development of new research that presents the transformation in the accounting services market, with an emphasis on the evolution from the concept of "occupation" to "profession" in the area of accounting. Other contributions to the history of accounting in Brazil could be presented through theoretical lenses capable of questioning the renewal of accounting, positioning it as a social practice that can influence and be influenced by the environment in which it operates. 


\section{REFERENCES}

Abbott, A. (1988). The system of professions: An essay on the division of expert labor. Chicago, IL: University of Chicago.

Azevedo, D. (2009). A evolução técnica e as transformações gráficas nos jornais brasileiros. Mediação, 9(9), 81-97.

Biasibetti, A. P., \& Feil, A. A. (2017). Análise do perfil do profissional contábil requerido pelas empresas do Vale do Taquari-RS. Revista Destaques Acadêmicos, 9(1), 89-110.

Bloch, M. L. B. (1992). The historian's craft. Manchester: Manchester University.

Câmara, B. A. D. (2007). Vassoura, balcão, escritório e rua: a caixeiragem como carreira. Almanack Braziliense, 6, 39-53.

Carr-Saunders, A. M. (1933). The professions. Oxford: The Clarendon Press.

Commercio. (1838, 27 de março). O Despertador, Diario Commercial, Politico, Scientifico e Litterario, p. 2-3. Retrieved from http://memoria.bn.br/DocReader/706701/10

Conselho Federal de Contabilidade (Federal Accounting Council). (2003). Abordagens éticas para o profissional contábil. Brasilia, DF: CFC. Retrieved from http://portalcfc. org.br/wordpress/wp-content/uploads/2013/01/livro_abord_ etica-pdf.pdf

Conselho Federal de Contabilidade (Federal Accounting Council). (2007). Caderno analítico do exame de suficiência: histórico dos resultados. Brasilia, DF: CFC.

Davies, C. (1980). Making sense of the census in Britain and the USA: The changing occupational classification and the position of nurses. Sociological Review, 28(3), 581-610.

Decree Law n. 5,452. (1942, May $\left.1^{\text {st }}\right)$. Approves the Consolidation of the Labor Laws. Retrieved from https://www2.camara.leg. br/legin/fed/declei/1940-1949/decreto-lei-5452-1-maio-1943415500-publicacaooriginal-1-pe.html

Decree-Law n. 9,295. (1946, May $\left.27^{\text {th }}\right)$. Creates the Federal Accounting Council, defines the attributions of an Accountant and a Bookkeeper, and makes other arrangements. Retrieved from http://www.histedbr.fe.unicamp.br/navegando/ fontes_escritas/6_Nacional_Desenvolvimento/decreto-lei\%20 n. $\% 209.295 \% 20 \% 96 \% 20$ de $\% 2027 \% 20$ de $\% 20$ maio $\% 20$ de $\% 20$ 1946\%20contador\%20ens\%20comercial.htm

Dingwall, R. (2008). Essays on professions. London: Ashgate.

Dubar, C. (2005). A socialização: construção das identidades sociais e profissionais. São Paulo, SP: Martins Fontes.

Gregório, V. M. (2011). Dividindo o Grão-Pará: os debates para a criação da província do Rio Negro na Câmara dos Deputados, 1826-1828. Almanack, (1), 137-152.

Hakim, C. (1980). Census reports as documentary evidence: The census commentaries 1801-1951. Sociological Review, 28(3), 551-580.

Hines, R. D. (1988). Financial accounting: in communicating reality, we construct reality. Accounting, Organizations and Society, 13(3), 251-261.

Hughes, E. C. (2009). The sociological eye: Selected papers. New Brunswick: Transaction Books.

Kreniski, G. C. P., \& Aguiar, M. do C. P. (2011). O jornal como fonte histórica: a representação e o imaginário sobre o "vagabundo" na imprensa brasileira (1989-1991). In Anais do Simpósio Nacional de História - ANPUH 26 (p. 1-14). São Paulo, SP.

Law n. 60 , of October $20^{\text {th }}$ of 1838 . Setting expenses and budgeting revenue for the 1939-1840 financial year. In Coleção das Leis do Império do Brasil de 1838 (Book I, Part I). Rio de Janeiro, RJ: Tipografia Nacional.

Lima, H. E., \& Popinigis, F. (2017). Maids, clerks, and the shifting landscape of labor relations in Rio de Janeiro, 1830s-1880s [Special Edition]. International Review of Social History, 62(25), 45-73.

Lopes, S. de N. (2002). Comércio interno no Pará oitocentista: atos, sujeitos sociais e controle entre 1840-1855 (Master's Dissertation). Universidade Federal do Pará, Belém.

Loraux, N. (1992). Elogio do anacronismo. In A. Novaes (Ed.), Tempo e história (pp. 57-69). São Paulo, SP: Companhia das Letras.

Macdonald, K. M. (1999). The sociology of the professions. London: Sage Publications.

Martinho, L. M. (1976). Organização do trabalho e relações sociais nas firmas comerciais do Rio de Janeiro (primeira metade do século XIX). Revista do Instituto de Estudos Brasileiros, (18), 41-62.

Martinho, L. M. (1993). Caixeiros e pés-descalços: conflitos e tensões em um meio urbaqno em desenvolvimento. In L. M. Martinho \& R. Gorenstein (Eds.), Negociantes e caixeiros na sociedade da independência (pp. 21-124). Rio de Janeiro, RJ: Secretaria Municipal de Cultura, Turismo e Esportes, Departamento Geral de Documentação e Informação Cultural, Divisão de Editoração.

Martins, L. R. (2015). Teoria das profissões e a análise dos fundamentos do serviço social. Verinotio, revista on-line, $X(20), 64-81$.

Morel, M. (2008). Os primeiros passos da palavra imprensa. In A. L. Martins \& T. R. Luca (Eds.), História da impresa no Brasil (pp. 23-44). São Paulo, SP: Contexto.

Netto, J. P. (2005). O movimento de reconceituação: 40 anos depois. Revista Serviço Social e Sociedade, XXVI(84), 5-19.

Neves, R. M. (2009). Anúncios classificados nos jornais impressos: o consumo da informação comercial. In VII Encontro Nacional de História da Mídia. Retrieved from http://www. ufrgs.br/alcar/encontros-nacionais-1/encontros-nacionais/7oencontro-2009-1/Anuncios\%20classificados\%20nos\%20 jornais\%20impressos.pdf

Nogueira, S. M. S. (2009). "A soldadesca desenfreada": politização militar no Grão-Pará da Era da Independência (1790-1850) (Doctoral Thesis). Universidade Federal da Bahia, Salvador.

Oliveira, R. (2013). Demandas por qualificação profissional: Recife, segunda metade do século XIX. Revista Brasileira de Educação, 18(54), 629-794.

Perrot, M. (2005). As mulheres ou os silêncios da história. Bauru, SP: Editora da Universidade do Sagrado Coração.

Pires, C. B., Ott, E., \& Damacena, C. (2009). Uma análise do perfil profissional requerido pelo mercado de trabalho para 
contadores na Região Metropolitana de Porto Alegre (RMPA) Revista Contabilidade Vista \& Revista, 20(3), 157-187.

Popinigis, F. (2007). Proletários de casaca: trabalhadores do comércio carioca, 1850-1911. Campinas, SP: Universidade Estadual de Campinas.

Popinigis, F. (2018). "Esperança e Fraternidade": o papel do associativismo na defesa do ofício e na reserva do mercado do trabalho no comércio para os portugueses - Rio de Janeiro, século XIX. In G. S. Ribeiro, P. C. Terra \& F. Popinigis (Eds.), Portugueses e cidadãos: experiências e identidades nos séculos XIX e XX (pp. 101-128). Rio de Janeiro, RJ: Mauad X, Fundação de Amparo à Pesquisa do Estado do Rio de Janeiro.

Rebouças, A. C. R. N., \& Bastos, A. K. P. H. (2017). Tradições discursivas dos anúncios publicitários nos jornais do Recife do século XIX e XXI. Retrieved from https://www.editorarealize. com.br/revistas/sinalge/trabalhos/TRABALHO_EV066_ MD1_SA13_ID800_22032017100236.pdf

Recenseamento do Brasil em 1872. (1874). Rio de Janeiro, RJ: Typ. G. Leuzinger.

Revel, J. (2009). Os usos da civilidade. In R. Chartier (Ed.), História da vida privada, 3: da Renascença ao Século das Luzes (pp. 169-210). São Paulo, SP: Companhia das Letras.
Rodrigues, L. L., Schmidt, P., \& Santos, J. L. (2012). The origins of modern accounting in Brazil: Influences leading to the adoption of IFRS. Research in Accounting Regulation, 24(1), 15-24.

Rueschemeyer, D. (1964). Doctors and lawyers: A comment on the theory of the professions. Canadian Review of Sociology, 1(1), 17-30.

Sales, A. J. (1761-1773). Diccionario do commercio [depois de 1723]. Retrieved from http://purl.pt/13945/4/

Salles, V. (1992). Memorial da Cabanagem. Belém, PA: Cejup.

Salles, V. (2004). O negro na formação da sociedade paraense. Belém, PA: Paka-Tatu.

Santos, M. A. da S. (2009). Casa e balcão: os caixeiros de Salvador (1890-1930). Salvador, BA: Universidade Federal da Bahia.

Silva, A. M. (1789). Diccionario da lingua portugueza composto pelo padre D. Rafael Bluteau, reformado, e accrescentado por Antonio de Moraes Silva natural do Rio de Janeiro (Vol. I, p. 417). Lisboa: Officina de Simão Thaddeo Ferreira.

Stroobants, M. (1997). Savoir-faire et compétence au travail. Bruxelles: Université de Bruxelles. 